\title{
HUBUNGAN PENGETAHUAN DENGAN SIKAP DETEKSI DINI KANKER SERVIKS PADA WANITA USIA DEWASA DI PUSKESMAS MALINAU TAHUN 2020
}

\author{
Tiara Lani ${ }^{*}$, Winda Rusanti
}

\author{
Program Studi Diploma Tiga Keperawatan Stikes Intan Martapura, Indonesia \\ Email : tiaralani.stikesintan@gmail.com
}

\begin{abstract}
ABSTRAK
Pendahuluan: Penyebab utama Kanker serviks adalah virus HPV (Human Papiloma Virus) yang merupakan penyakit kedua terbanyak bagi perempuan setelah kanker payudara, peningkatan angka kejadian kanker pada wanita disebabkan rendahnya pemeriksaan deteksi dini pada wanita usia dewasa.Tujuan: Penelitian ini mengetahui hubungan pengetahuan dengan sikap deteksi dini Kanker serviks pada wanita usia dewasa di Puskesmas Malinau. Metode: Desain penelitian deskriptif analitik, desain menggunakan korelasi dengan pendekatan cross sectional dengan populasi sebanyak 830 orang, teknik sampel yang digunakan adalah accidental sampling dengan jumlah sampel 50 responden. Analisis ini disajikan dalam tabel distribusi frekuensi. Hasil: terdapat hubungan pengetahuan dan sikap terhadap deteksi dini kanker serviks pada wanita usia dewasa yang dilakukan dengan Uji Spearman Rank, diperoleh nilai $\mathrm{p}=$ 0,000. Dengan demikian $\mathrm{p}<\mathrm{a}$, dan diketahui Correlation coefficient (koefisien korelasi)0,688 , maka $\mathrm{H}_{1}$ diterima. Kesimpulan: Dalam meningkatkan drajat kesehatan di Indonesia, khususnya di wilayah puskesmas Malinau Kalimantan Selatan terhadap kejadian kanker serviks yaitu dengan skiring atau deteksi dini kanker serviks secara optimal dengan penatalaksanaan yang adekuat dari pelayanan kesehatan dalam menurunkan angka kejadian kanker serviks.
\end{abstract}

Kata kunci: pengetahuan, sikap, deteksi dini kanker serviks

\section{ABSTRACT}

Introduction: The main cause of cervical cancer is the HPV (Human Papilloma Virus) which is the second most common disease for women after breast cancer. Aim: This study investigates the relationship between knowledge and attitudes towards early detection of cervical cancer in adult women at the Malinau Public Health Cente. Methods: The research method uses descriptive analytic, the design uses correlation with cross sectional approach with a population of 830 people, the sample technique used is accidental sampling with a sample size of 50 respondents. This analysis is presented in the frequency distribution table. Result: The results of this study stated that there was a relationship between knowledge and attitude towards early detection of cervical cancer in adult women performed by the Spearman Rank Test, obtained $p=0,000$. Thus $p<a$, and known Correlation coefficient (correlation coefficient) 0.688, then $\mathrm{H} 1$ is accepted. Discussionn: In improving health status in Indonesia, specially in the Malinau Public Health Center, South Kalimantan, to the incidence of cervical cancer, namely by screening or early detection of cervical cancer optimally with adequate management of health services in reducing the incidence of cervical cancer.

Key word: knowledge and attitude, early detection of cervical cancer.

Cite this as : $\quad$ Lani, T, Rusanti, W.(2021). Hubungan Pengetahuan dengan Sikap Deteksi Dini Kanker Serviks pada Wanita Usia Dewasa di Puskesmas Malinau Tahun 2020. Jurnal Ilmu Kesehatan Insan Sehat, 9(1), 30-32.

\section{PENDAHULUAN}

Kanker serviks salah satu masalah kesehatan di Indonesia maupaun di dunia terhadap wanita dewasa, yang utamanya disebabkan virus HPV (Human Papiloma Virus) yang merupakan penyakit kedua terbanyak bagi perempuan setelah kanker payudara. Fungsi serviks sebagai jalan lahir dan pemisah antara rahim dengan vagina, kanker serviks terjadi karena adanya kelainan pada pada jalur pemisah tersebut (Tilong, 2012).
Di dunia penderita kanker serviks mencapai dua puluh juta setiap tahun, di antaranya Negaranegara berkembang seperti Asia Selatan, Asia Tenggara. Pada tahun 2012 kasus kanker cukup tinggi yaitu sebesar 445 ribu jiwa di seluruh dunia dan sebanyak 270 ribu jiwa wanita dewasa meniggal akibat kanker serviks (WHO, 2015).

Pada tahun 2017 di Indonesia terjadi peningkatan kasus kanker serviks sekitar 15 ribu kasus dan 7493 jiwa wanita yang terkena kanker serviks 
berakhir dengan kematian, peingkatan kasus ini terjadi disebabkan kurangnya deteksi dini kanker, sekitar 70\% dari kasus ditemukan sudah dalam keadaan stadium akhir (Kemenkes, 2017). Di Kalimantan selatan Prevalensi kanker serviks di tahun 2013 adalah sebesar 1,6 \% atau diperkirakan sebanyak 6.145 penderita diperoleh data dari Ketua Yayasan Kanker Indonesia Kal-Sel (Dinkes, 2018).

Meningkatnya Angka kejadian kanker serviks di Indonesia diantaranya tingkat kesadaran yang kurang terhadap kesehatan dan minimnya pengetahuan terhadap kanker serviks, pada penyakit kanker sebenarnya pada dasarnya sudah terdapat banyak pengobatan yang dapat digunakan oleh mansyarakat sehingga dapat menurunkan angka kejadian kanker dan kematian akibat penyakit ini. Semua perempuan berisiko tinggi akan terjadinya kanker serviks dikarenakan kesiapan pada sistem reproduksi pada wanita mengalami tingkat kesuburan pada usia 20 tahun, faktor yang diresikokan pada wanita subur yaitu pada usia muda $<20$ tahun dianggap masih terlalu muda karena kesiapan organ reproduksi yang belum cukup matang. Apabila hal ini dibiarkan akan berdampak pada tingginya kasus kanker serviks di Indonesia (Departemen Kesehatan RI,2016).

\section{METODE}

Desain penelitian ini deskriptif analitik korelasi dengan pendekatan cross sectional dengan populasi sebanyak 830 orang, jumlah sampel 50 dengan teknik accidental sampling. Data diambil dengan menggunakan kuesioner.

\section{HASIL}

\section{Tabel 1: Distribusi Frekuensi Responden} Berdasarkan Umur

\begin{tabular}{lll}
\hline \multirow{2}{*}{ Usia Responden (tahun) } & \multicolumn{2}{c}{ Usia } \\
\cline { 2 - 3 } & Rata-Rata & Min-Max \\
\cline { 2 - 2 } & 63,5 & $26-45$ \\
\hline
\end{tabular}

Berdasarkan data tabel di atas didapatkan hasil bahwa mayoritas responden pada penelitian ini berusia 26 sampi 30 tahun.

\section{Tabel 2: Distribusi Frekuensi Responden Berdasarkan Tingkat Pendidikan}

\begin{tabular}{llcc}
\hline No & \multicolumn{1}{c}{ Pendidikan } & Jumlah & Persen (\%) \\
\hline 1 & SD/Sederajat & 3 & 6,0 \\
2 & SLTP/Sederajat & 1 & 2,0 \\
3 & SLTA/Sederajat & 23 & 46,0 \\
\hline 4 & Perguruan Tinggi & 23 & 46,0 \\
\hline & Total & $\mathbf{5 0}$ & $\mathbf{1 0 0}$ \\
\hline
\end{tabular}

Berdasarkan data tabel di atas didapatkan hasil bahwa tingkat pendidikan responden di Puskesmas Malinau rata-rata SMA dan perguruan tinggi.

\section{Tabel 3: Distribusi Frekuensi Responden Berdasarkan Riwayat Perkawinan}

\begin{tabular}{llcc}
\hline No & \multicolumn{1}{c}{ Status } & Jumlah & Persen (\%) \\
\hline 1 & Menikah & 47 & 94,0 \\
2 & Belum menikah & 3 & 6,0 \\
\hline \multicolumn{2}{l}{ Total } & $\mathbf{5 0}$ & $\mathbf{1 0 0}$ \\
\hline
\end{tabular}

Berdasarkan data tabel di atas didapatkan hasil bahwa riwayat perkawinan responden di Puskesmas Malinau mayoritas dengan responden yang sudah menikah sejumlah 47 responden (94\%).

Tabel 4: Hasil Uji Accidental sampling

\begin{tabular}{|c|c|c|c|c|c|c|}
\hline \multirow[t]{2}{*}{ No } & \multirow{2}{*}{$\begin{array}{c}\text { Tingkat } \\
\text { pengetahuan }\end{array}$} & \multicolumn{2}{|c|}{ Sikap } & \multirow[t]{2}{*}{ Total } & \multirow[t]{2}{*}{ Nilai p } & \multirow[t]{2}{*}{ Rho } \\
\hline & & Positif & Negatif & & & \\
\hline 1 & Baik & $\begin{array}{c}34 \\
(68 \%)\end{array}$ & $\begin{array}{c}3 \\
(6, \%)\end{array}$ & $\begin{array}{c}37 \\
(100 \%)\end{array}$ & $<0,001$ & 0,688 \\
\hline 2 & Cukup & $\begin{array}{c}3 \\
(6 \%)\end{array}$ & $\begin{array}{c}10 \\
(20 \%)\end{array}$ & $\begin{array}{c}17 \\
(100 \%)\end{array}$ & & \\
\hline & Total & $\begin{array}{c}37 \\
(74 \%)\end{array}$ & $\begin{array}{c}13 \\
(26 \%)\end{array}$ & $\begin{array}{c}50 \\
(100 \%)\end{array}$ & & \\
\hline
\end{tabular}

Berdasarkan tabel 4 menyajikan data dari 50 responden, dapat dilihat bahwa sebanyak 34 responden atau $68 \%$ responden memiliki pengetahuan dengan sikap yang baik, dan sebanyak 3 responden atau $6 \%$ responden memiliki pengetahuan cukup baik dengan sikap yang positif, hasil uji analisis menggunakan uji statistik Spearman Rank didapatkan nilai $\rho=0,000<\alpha$ 0,05 sehingga disimpulkan bahwa Ha diterima dan Ho ditolak yang berarti ada hubungan yang signifikan antara pengetahuan dengan sikap deteksi dini kanker serviks wanita usia dewasa di Puskesmas malinau tahun 2020. Dengan nilai kolerasi koefisien sebesar 0,688 dengan arah korelasi positif dengan kekuatan kolerasi kuat.

\section{PEMBAHASAN}

Pengetahuan terhadap kajadian kanker serviks yang biasanya lebih banyak terjadi pada wanita dewasa dan wanita yang aktif secara seksual sangat penting untuk menurunkan angka kejadian kanker, pengetahuan juga sangat berpengaruh terhadap sikap seseoarang dalam berprilaku terhadap kesehatan dirinya, tingkat pengetahuan sesorang terhadap kanker seviks di tunjukan dengan adanya pemahaman terhadap apa yang dimaksud dengan deteksi dini dan pentingnya deteksi dini kanker serviks dimasa sekarang, hal ini sesuai dengan hasil penelitian (Artiningsih, A, 2011) bahwa pengetahuan yang dimiliki seseorang mempengaruhi sikapnya terhadap perilaku kesehatan dan sebaliknya seseorang yang memiliki pengetahuan kurang dapat dilihat dari sikap yang kurang peduli terhadap kesehatannya di antaranya pemeriksaan dini kanker serviks. 


\section{KESIMPULAN}

Dari hasil penelitian disimpulkan bahwa ada hubungan antara pengetahuan dengan sikap terhadap deteksi dini kanker servik pada wanita usia dewasa di Puskesmas Malinau tahun 2020, dengan jumlah sampel sebanyak 50 responden di dapatkan hasil tingkat pengetahuan baik dengan sikap Positif sebanyak 34 responden atau sebanyak $68,0 \%$.

\section{SARAN}

Kanker serviks masih menjadi masalah kesehatan di Indonesia dan dunia yang tidak dapat dihindari hingga saat ini sampai akan datang, untuk itu dalam meningkatkan drajat kesehatan di Indonesia, khususnya di wilayah puskesmas Malinau Kalimantan Selatan terhadap kejadian kanker serviks dengan skiring atau deteksi dini kanker serviks secara optimal dengan penatalaksanaan yang adekuat dari pelayanan kesehatan dalam menurunkan angka kejadian kanker serviks.

\section{DAFTAR PUSTAKA}

Alimul Hidayat, A Aziz. 2007. Metode Penelitin Keperawatan dan Teknik Analisis Data. Jakarta: Salemba Medika

Artiningsih, A, 2011, Hubungan antara Pengetahuan dan Sikap WUS dengan Pemeriksaan IVA dalam Rangka Deteksi Dini Kanker Serviks di Wilayah Puskesmas Blooto Kota Mojokerto, Tesis, Pasca Sarjana Kedokteran Keluarga, UNS

Balitbangkes. Riset Kesehatan Dasar (Riskesdas). (2018). Jakarta : Badan Penelitian dan Pengembangan Kesehatan, Kementrian Kesehatan RI.

Brunner dan Suddarth (2013). Buku Ajar Keperawatan Medikal Bedah Brunner \& Sudarth.Vol 2. Edisi 8.Editor ;Smeltzer SC, Bare BG. Jakarta : EGC.

Darmadi, Hamid. 2013. Metode Penelitian Pendidikan dan Sosial. Bandung: Alfabeta

Dogan O., Ertekin S., Dogan S. et al. 2005. Sleep quality in hospitalized patients. Journal of Clinical Nursing. 14; 107-113.

Fatmadona, A, Oktarina, E 2016 'Aplikasi Modern Wound Care Pada Perawatan Luka Infeksi', Ners Jurnal Keperawatan, Vol.12, no hh. 159-165

Gitarja, W, S 2019, Pelatihan Perawatan Luka Bagi Praktisi Kesehatan Di Fasilitas Pelayanan Kesehatan, Bogor, Yayasan Wocare Indonesia.

Guyton and Hall. 2007. Buku Ajar Fisiologi Kedokteran dan Mekanisme Mekanisme Penyakit. Jakarta: EGC

Hendra, AW. 2008, Faktor-Faktor Yang Mempengaruhi Pengetahuan, Jakarta : Pustaka Sinar. Harapan
Kartika, R. W., 2015. Perawatan Luka Kronis dengan Modern Dressing, CDK-230, 42(7), hal.546-550.

Kozier, B., Erb, G., Berman, A., 7 Snyder, S. 2011. Buku ajar keperawatan : konsep, proses dan praktik alih bahasa Pamilih Eko Karyuni. Jakarta: EGC

Notoatmodjo, S. 2003. Pendidikan dan Prilaku Kesehatan. Jakarta : Rineka Cipta.

Nursalam. (2008). Konsep dan Penerapan Metodologi Penelitian Ilmu Keperawatan Pedoman Skripsi, Tesis dan Instrumen Penelitian Keperawatan. Jakarta: Salemba Medika.

Sugiyono. 2013. Metode Penelitian Pendidikan Pendekatan Kuantitatif, Kualitatif, dan $R \& D$. Bandung: Alfabeta.

Sussman, C., \& Jensen, B. B. (2007). Wound Care. USA: Hearthside Publishing Services

WHO. Global Report On Diabetes. France: World Health Organization; 2016. 